\title{
INDEK SUBJEK
}

A

anak usia dini, $.1,2,4,5,11,12$, $16,17,19,21,27,28,29,31,33,34,37,38,39$, $43,69,86,88,89,90,91,92,94,95,96,99$, 100

\section{G}

gender, $86,87,88,89$ 90, 91, 92, 94, 95, 96, 97, 98, 99, 100

\section{$\mathbf{H}$}

homeschooler $75,77,78,80$, $82,83,84$

\section{K}

keberhasilan program kecakapan hidup, 113, 121

kecerdasan emosi, $18,19,20,21$ $27,28,29,30,31$

keefektifan $.1,4,5,7,8,9$

$13,14,15,16,118$

kemiskinan, $.52, \quad 101, \quad 102$ $103,104,107,112$

kerja sama pendidik dan orangtua, 18, 26, 31 kesejahteraan sosial $101,103,104$ 107

kompetensi parenting, $32,36,38,39$ $40,42,46,48$.

Komunitas Belajar $50,54,55,57$ $58,61$.
$\mathbf{L}$

LPM, .................................101, 106, 107, 108, 109, 110, 111, 112

\section{M}

Modeling, $63,65,66,67$, $69,70,72,73,74,76,81$.

\section{$\mathbf{N}$}

nilai-nilai, $19,41,45,66$, $75,77,78,79,80,82,83,84,89,90,91,92$, 93, 94, 95, 97, 99, 105, 117

nonformal, $2,3,48,52,53$ $55,61,64,65,66,67,72,76,77,79,80,81$, 89, 101, 103, 104, 105, 106, 107, 108, 109, 110, 111, $112,120,122,123$

\section{$\mathbf{O}$}

Orsos, 101, 104, 106, $107,108,109,110,111,112$

\section{$\mathbf{P}$}

PAUD, $1,2,3,4,5,6$ $7,8,9,10,11,12,13,14,15,16,17,19,20,21,22$, 30, 33, 48

Pelaksanaan program kecakapan hidup, 113, 121

pemberdayaan, 2, 87, 101, 104, 105, 106, 107, 108, 109, 111, 112

pendidikan, $2,3,5,7,9,10$ $12,19,20,22,23,27,29,31,33,35,42,45,47$, 48, 50, 51, 52, 53, 54, 53, 54, 55, 56, 57, 59, 61, 
$63,64,65,67,71,73,75,76,77,78,79,80,81$, $83,84,83,84,85,86,87,88,89,90,91,93$, 94, 95, 96, 97, 99, 100, 101, 102, 103, 104, 105, 106, 107, 108, 109, 110, 109, 110, 111, 112, 116, 117, 118, 119, 123

Pendidikan Alternatif, $50,52,53,61$

pendidikan karakter, $75,76,77,78$ $79,80,81,82,83,84,85$

pengasuhan orangtua, $18,20,21,22$, $26,28,30,37,42,43,45$

pengasuhan pendidik, $.18,21,22,23$ $24,26,27,28,29,30$ pengembangan aspek personal dan sosial, $63,67,72$

perkembangan sosial anak, ...32, 34, 36, 37, $38,39,40,41,42,43,44,45,46$

PKBM, 101, 104, 106, 107, 108, 109, 110, 111, 112

\section{$\mathbf{T}$}

team teaching, $.1,4,5,6,7,8$, $9,10,11,13,14,15,16,17$ 


\section{INDEKS PENGARANG}

$\mathbf{E}$

Erifiani, Benny,

$\mathbf{F}$

Fauziah, Puji Yanti,

1, 75

H

Haryanti,

32

\section{K}

Kuntoro, Sodiq Azis 50,71

Kusniapuantari, Daning

M

Miradj, Safri 101
$\mathbf{R}$

Roziqoh, 86

S

Shofwan, Imam …….................................50

Sumarno, 32, 101, 117

Suparno, 86

Suryono, Yoyon $18,63,113,117,118,123$ Susilo, Nyudi Dwijo .63

T

Tristanti, 113

V

Vibriyanthy, Ricca .75 


\section{BIODATA PENULIS}

\section{Benny Erifiani}

Benny Erifiani dilahirkan di Kulon Progo, pada tanggal 7 September 1984. Tahun 2008 lulus Program S1 pada Program Studi Pendidikan Geografi, Fakultas Ilmu Sosial Universitas Negeri Yogyakarta dan pada tahun 2013 telah menyelesaikan S2 di Program Studi Pendidikan Luar Sekolah Program Pascasarjana Universitas Negeri Yogyakarta. Benny Erifiani telah bekerja di Dinas Pendidikan Kabupaten Kulon Progo

\section{Daning Kusniapuantari}

Daning Kusniapuantari lahir di Bantul pada tanggal 28 Oktober 1980. Daning memperoleh gelar sarjana pada Program Studi Teknologi Hasil Pertanian Universitas Wangsa Manggala tahun 2007. Program Magister lulus pada tahun 2013 pada Program Studi Pendidikan Luar Sekolah Program Pascasarjana Universitas Negeri Yogyakarta. Daning pernah bekerja di Kelompok Bermain ALBHA (Alumni Bimbingan Haji "Aisyiah) Wates dan saat ini bekerja KB Citragami Kulon Progo

\section{Haryanti}

Haryanti lahir di Sleman pada tanggal 14 Agustus 1975. Dia telah lulus dari Program S1 pada Program Studi Manajemen Syariah di Perguruan Tinggi STEI Yogyakarta tahun 2008 dan Program S2 pada Program Studi Pendidikan Luar Sekolah Program Pascasarjana Universitas Negeri Yogyakarta tahun 2013. Saat ini bekerja sebagai tenaga pengajar di Lembaga PAUD Bim Bim Cha Condongcatur Yogyakarta

\section{Imam Shofwan}

Lahir di Pati pada tanggal 10 Juli 1984. Pada tahun 2006 lulus dari Program Studi Pendidikan Luar Sekolah Universitas Negeri Semarang, kemudian melanjutkan kuliah S2 di Program Studi Pendidikan Luar Sekolah Program Pascasarjana Universitas Negeri Yogyakarta dan lulus tahun 2013. Imam Sofwan pernah bekerja di Primagama Cabang Salatiga. Saat ini Imam bekerja di IKIP Veteran Semarang

\section{Nyudi Dwijo Susilo}

Nyudi dilahirkan di Ponorogo tanggal 5 Februari 1982. Gelar sarjana diperoleh dari Program Studi Pendidikan Bahasa Jerman Fakultas Bahasa dan Seni Universitas Negeri Yogyakarta pada tahun 2007. Pada tahun 2009 melanjutkan Program S2 di Prodi Pendidikan Luar Sekolah Program Pascasarjana UNY. Saat ini bekerja di LKP Colour Models Management Yogyakarta.

\section{Puji Yanti Fauziah}

Puji Yanti Fauziah dilahirkan di Cianjur pada tanggal 13 Februari 1981. Gelar Sarjana diperoleh pada tahun 2003 dari Prodi Pendidikan Luar Sekolah FIP UNY. Gelar Magister dan Doktor didapatkan dari Universitas Pendidikan Indonesia pada tahun 2007 dan 2011. Saat ini bekerja sebagai dosen pada Prodi Pendidikan Luar Sekolah FIP UNY dan Program Pascasarjana UNY. 


\section{Ricca Vibriyanthy}

Ricca dilahirkan di Jakarta pada tanggal 1 September 1986. Gelar S1 didapatkan dari Program Studi Pendidikan Luar Sekolah Universitas Negeri Jakarta pada tahun 2010, kemudian melanjutkan Program S2 Program Studi Pendidikan Luar Sekolah Program Pascasarjana Universitas Negeri Yogyakarta pada tahun 2011. Saat ini bekerja sebagai tentor di Sanggar Kegiatan Belajar.

\section{Roziqoh}

Roziqoh dilahirkan di Cirebon, 28 Juli 1978. Program Sarjana diselesaikan pada tahun 2010 pada Prodi Pendidikan Agama Islam Sekolah Tinggi Agama Islam (STAI) Cirebon. Program Magister lulus pada tahun 2013 pada Program Studi Pendidikan Luar Sekolah Program Pascasarjana Universitas Negeri Yogyakarta. Roziqoh saat ini bekerja sebagai staf pengajar di Fakultas Tarbiyah Institut Studi Islam Fahmina Cirebon.

\section{Safri Miradj}

Safri Miradj dilahirkan di Ternate pada tanggal 9 April 1985. Setelah menamatkan Program Sarjana di Prodi Pendidikan Agama Islam Sekolah Tinggi Agama Islam Negeri (STAIN) Ternate pada tahun 2010, Safri Miradj melanjutkan Program Magister di Program Studi Pendidikan Luar Sekolah Program Pascasarjana Universitas Negeri Yogyakarta pada tahun 2011. Saat ini bekerja di Fakultas Keguruan dan Ilmu Pendidikan Universitas Muhammadiyah Maluku Utara

\section{Sodiq Aziz Kuntoro}

Guru Besar Emiritus Jurusan Pendidikan Luar Sekolah Fakultas Ilmu Pendidikan Universitas Negeri Yogyakarta. Memperoleh gelar S1 pada Jurusan Pendidikan Sosial IKIP Yogyakarta dan gelar Magister Sosiologi Pendidikan Universitas Hirosima, Jepang, dan gelar Doktor dari IKIP Jakarta.

\section{Sumarno}

Dosen Jurusan Pendidikan Luar Sekolah Fakultas Ilmu Pendidikan Universitas Negeri Yogyakarta dalam mata kuliah Pendidikan dan Pembangunan, dan Manajemen Program. Gelar BA dan Drs dari jurusan Pendidikan Sosial Institut Keguruan dan Ilmu Pendidikan (IKIP) Yogyakarta diperoleh pada tahun 1972. Gelar MA diperoleh pada tahun 1980 dan gelar Ph.D pada Perencanaan dan Sosiologi Pendidikan tahun 1986 dari Macquire University, Sydney Australia.

\section{Suparno}

Lektor kepala Jurusan Pendidikan Luar Sekolah Fakultas Ilmu Pendidikan Universitas Negeri Yogyakarta. Memperoleh gelar Sarjana bidang Pendidikan Luar Biasa Universitas Pendidikan Indonesia tahun 1985, dan gelar Magister Pendidikan dari Pendidikan Luar Sekolah Universitas Pendidikan Indonesia tahun 1995. Gelar Doktor diperoleh dari Universitas Negeri Jakarta pada Bidang Pendidikan Anak Usia Dini pada tahun 2011. 


\section{Tristanti}

Tristanti dilahirkan di Purworejo pada tanggal 8 Juli 1989. Program sarjana ditamatkan di Prodi Pendidikan Luar Sekolah Fakultas Ilmu Pendidikan Universitas Negeri Yogyakarta pada tahun 2011, kemudian dilanjutkan program S2 pada Pendidikan Luar Sekolah Program Pascasarjana Universitas Negeri Yogyakarta dan lulus pada tahun 2013. Saat ini bekerja sebagai tenaga pengajar di Universitas Negeri Yogyakarta.

\section{Yoyon Suryono}

Guru Besar Ilmu Evaluasi Pendidikan Nonformal pada Jurusan Pendidikan Luar Sekolah Fakultas Ilmu Pendidikan Universitas Negeri Yogyakarta. Memperoleh BA dan Drs pada Jurusan Pendidikan Sosial IKIP Yogyakarta pada tahun 1977, Magister Sains (M.S.) dari Sekolah Pascasarjana Institut Pertanian Bogor pada tahun 1984, dan pada tahun 2006 memperoleh gelar Doktor Pendidikan dari Program Pascasarjana Universitas Negeri Yogyakarta. 


\section{KETENTUAN PENULISAN ARTIKEL JPPM}

1. Artikel yang dimuat merupakan hasil penelitian dan kajian ilmiah tentang pendidikan Formal dan Nonformal yang belum pernah dipublikasikan.

2. Panjang artikel 10-15 halaman, 1 spasi, kertas kwarto A4, margin: kiri dan atas $3 \mathrm{~cm}$, kanan dan bawah $2 \mathrm{~cm}$, font: Constantia 11

3. Artikel dibuat rangkap dua (Hard file dan Soft file dikirim via email) dikirim ke Sekretariat Dewan Redaksi JPPM Program Studi S2 Pendidikan Luar Sekolah, Program Pascasarjana, Universitas Negeri Yogyakarta (UNY), Gedung Program Pascasarjana Lantai 3, Jl. Colombo No. 1, Karangmalang Yogyakarta 55281, Telp: (o274) 586168 pesawat 229 atau (o274) 550836, Fax: (0274) 520326, dan bisa dikirim via Email: journal.pps@uny.ac.id. Format penulisan artikel mengikuti template yang ada (atau minta dikirimkan via email)

4. Artikel ditulis menggunakan bahasa Indonesia baku

5. Judul dalam bahasa Indonesia, ditulis dengan huruf Constantia -11 bold, maksimal 14 kata, rata tengah. Untuk judul versi bahasa Inggris ditulis dengan huruf Constantia-11 bold, rata tengah. Judul harus jelas, informatif, menarik, visioner, aktual, dan mengandung kata kunci.

6. Nama penulis ditulis tanpa gelar dengan mencantumkan instansi asal dan alamat email.

7. Abstrak ditulis dalam bahasa Inggris dan bahasa Indonesia, terdiri atas 100 hingga 200 kata yang ditulis dalam narasi paragraf, memuat:

a. Hasil Penelitian: tujuan, metode, dan hasil penelitian.

b. Kajian ilmiah: permasalahan dan pembahasan.

diketik 1 spasi, disertai dengan kata kunci yang mencerminkan substansi artikel.

8. Isi atau batang tubuh artikel memuat:

a. Hasil Penelitian:

Judul, nama penulis tanpa gelar, instansi asal, alamat email, abstrak, kata kunci, isi meliputi: Pendahuluan: latar belakang, permasalahan, dan landasan teori (dengan ketentuan latar belakang, permasalahan, dan landasan teori tidak ditulis dalam sub-bab tetapi menjadi satu bagian); Metode; Hasil dan Pembahasan; dan Simpulan), Daftar Pustaka, dan biodata penulis.

b. Kajian ilmiah:

Judul, nama penulis tanpa gelar, instansi asal, alamat email, abstrak, kata kunci, isi (Pendahuluan, Pembahasan, dan Simpulan), daftar pustaka, dan biodata penulis.

9. Penunjukan sumber acuan, daftar pustaka dan tabel ditulis dengan format gaya APA Style:

10. Gambar, grafik, dan tabel disajikan dengan ketentuan :

a. Foto untuk gambar harus cukup tajam dan jelas.

b. Ukuran gambar, grafik, tabel, dan sebagainya disesuaikan dengan ukuran kertas

c. Gambar dan grafik dibuat di atas kertas putih dan diberi nomor urut dan diacu dalam teks.

d. Judul tabel di tengah atas

e. Judul gambar, grafik, ditulis di tengah bawah

11. Biodata penulis ditulis dalam bentuk narasi/paragraf, maksimum 150 kata, memuat nama lengkap dan gelar pendidikan, tempat dan tanggal lahir, pekerjaan, nama lembaga/instansi tempat bekerja, nomor telephone dan alamat email.

12. Beberapa kemungkinan tentang artikel yang dikirimkan: (diterima dan diterbitkan, diterima dengan perbaikan oleh redaksi, diperbaiki untuk dipertimbangkan kembali, ditolak karena tidak memenuhi syarat)

13. Artikel yang tidak diterbitkan akan dikembalikan bila disertai amplop beralamat penulis dan perangko secukupnya.

14. Batasan jumlah artikel yang dimuat adalah 9 artikel per edisi

15. Isi artikel sepenuhnya menjadi tanggung jawab penulis.

16. Batas pengiriman artikel maksimal 1 bulan sebelum terbit. 